\title{
Revitalisasi Lapangan Desa Masaran, Kecamatan Masaran, Kabupaten Sragen
}

\author{
Tri Hartanto ${ }^{1}$, A. Bambang Yuwono ${ }^{2}$ \\ ${ }^{(1)}$ Program Studi Arsitektur, Fakultas Teknik, Universitas Tunas Pembangunan (UTP) \\ Surakarta, e-mail: tri.hartanto23@yahoo.com \\ ${ }^{(2)}$ Program Studi Arsitektur, Fakultas Teknik, Universitas Tunas Pembangunan (UTP) \\ Surakarta, e-mail: bamban.yuuwono@gmail.com
}

\begin{abstract}
The Masaran Village Field, Masaran Subdistrict, Sragen Regency which has so far been felt to be of diminishing benefits to the community, will be developed according to the needs of the community today. Wide field, can be managed for various purposes. Not only in the field of sports, but also in the field of recreation and economics. Provision of a container for selling, is expected to encourage the community to sell their products. Field revitalization, closely related to spatial planning in the area of the field, includes drainage systems, environmental road systems, inundation / flood control, and greening. The service method goes through several stages. The first stage is preparation, namely by holding discussions with the village officials of Masaran and community leaders. The next step is to create a pre-designed drawing in the form of a site plan, floor plan and perspective. From the pre-designed material that has been compiled, discussions are carried out with all village teams and apparatus and community leaders to obtain input and suggestions for pre-design improvements. After obtaining approval, detailed drawings are made. Planning is planned by a team of experts in their fields, to prepare a master plan for the revitalization of the Masaran field development. The output of this service is the compilation of Work Drawings and Budget and Cost Plans (RAB) for the revitalization of the Masaran field. Based on this, the collaboration between the village government and universities in the future will be increased so that it will bring benefits to the community.
\end{abstract}

Keywords: revitalization; village field; spatial planning.

\begin{abstract}
Abstrak
Lapangan Desa Masaran, Kecamatan Masaran, Kabupaten Sragen yang selama ini dirasakan semakin berkurang manfaatnya bagi masyarakat, akan dikembangkan sesuai dengan kebutuhan masyarakat saat ini. Lapangan yang luas, dapat dikelola untuk berbagai kepentingan. Tidak hanya di bidang olah raga, namun juga bidang rekreasi dan ekonomi. Penyediaan wadah untuk berjualan, diharapkan mampu mendorong masyarakat bisa menjual produknya. Revitalisasi lapangan, terkait erat dengan penataan ruang kawasan di lingkup lapangan, meliputi sistem drainase, sistem jalan lingkungan, pengendalian genangan/banjir dan penghijauan. Metode pengabdian melalui beberapa tahap. Tahap pertama adalah persiapan, yaitu dengan melakukan diskusi dengan perangkat desa Masaran dan tokoh masyarakat. Tahap berikutnya adalah membuat gambar pra-desain berupa gambar site-plan, denah dan perspektif. Dari bahan pra-desain yang telah disusun, dilakukan diskusi dengan semua tim dan perangkat desa dan tokoh masyarakat untuk mendapatkan masukan dan saran untuk perbaikan pra-desain. Setelah mendapat persetujuan maka dibuat gambar detailnya.
\end{abstract}


Perencanaan direncanakan oleh tim ahli di bidangnya, untuk menyiapkan master plan revitalisasi pembangunan lapangan Masaran. Luaran dari pengabdian ini adalah tersusunnya Gambar Kerja dan Rencana Anggaran dan Biaya (RAB) untuk revitalisasi lapangan desa Masaran. Berdasarkan hal tersebut maka kolaborasi antara pemerintah desa dan perguruan tinggi ke depannya ditingkatkan sehingga membawa manfaat bagi masyarakat.

Kata Kunci: revitalisasi; lapangan desa; penataan ruang.

\section{PENDAHULUAN}

Menurut Ellizar (2017), penataan ruang luar pada dasarnya merupakan pemanfaatan ruang hidup yang ada pada site, untuk diolah sedemikian rupa, untuk dikembangkan segala potensinya sehingga menjadi ruang yang berfungsi dengan baik. Dalam penataan ruang tersebut, harus dipertimbangkan segala faktor, baik fisik maupun non fisik agar tercipta sebuah penataan ruang luar yang baik dan benar.

Revitalisasi adalah suatu proses atau cara dan perbuatan untuk menghidupkan kembali suatu hal yang sebelumnya terberdaya sehingga revitalisasi berarti menjadikan sesuatu atau perbuatan untuk menjadi vital. Sedangkan, vital mempunyai arti sangat penting atau sangat diperlukan sekali untuk kehidupan dan sebagainya.

Desa Masaran mempunyai wilayah yang berbatasan langsung dengan desa-desa di sekitarnya. Sisi utara desa tersebut berbatasan dengan Desa Krikilan dan Desa Pringanom, Wilayah selatan berbatasan dengan Desa Karangmalang dan Desa Krebet. Wilayah Timur berbatasan dengan Desa Dawungan dan Desa Gebang. Untuk Wilayah Barat berbatasan dengan Desa Jati dan Desa Pringanom. Wilayah Desa Masaran terletak di pusat wilayah Kecamatan Masaran, Kabupaten Sragen, Jawa Tengah. Wilayah tersebut memiliki posisi yang strategis karena berada di titik pertemuan jalur SoloSurabaya. Kondisi tersebut membawa efek pertambahan penduduk secara cepat sehingga meningkatkan mobilisasi manusia dan barang. Suatu wilayah yang pertumbuhan infrastruktur tidak terencana dapat menyebabkan tidak optimalnya proses kegiatan sosial dan ekonomi daerah tersebut. Perlu adanya pendampingan dalam proses perencanaan salah satu komponen infrastruktur guna mulai meminimalisir kegagalan pertumbuhan infrastruktur.

Melalui artikel ini, pengabdi bermaksud menambah wawasan tentang konsep revitalisasi lapangan desa Masaran, yang belakangan kurang bermanfaat dan dapat dioptimalkan fungsinya sesuai dengan potensi dan karakteristik desa. Revitalisasi semestinya mengedepankan local wisdom dari masyarakat setempat sehingga tidak terjadi keseragaman konsep dan bentuk revitalisasi lapangan yang didukung oleh keberadaan dana desa dari pemerintah pusat.

\section{METODE PENELITIAN}

Dalam program pengabdian ini, posisi tim pengabdian masyarakat dari Fakultas Teknik Universitas Tunas Pembangunan Surakarta, sebagai pendamping/konsultan yang tidak mempunyai kewenangan memutuskan. Otoritas tim pengabdian masyarakat ini hanya memberikan saran dan usulan yang bersifat membangun dalam koridor rasional dan terukur.

Tahap awal dari pendampingan, dilaksanakan sebagai berikut: a) melakukan kompilasi data pengukuran, dokumentasi foto dan lain-lain sebagai bahan untuk proses analisis, b) melakukan analisis tapak terhadap kondisi tapak lokasi lapangan Masaran, 
c) melakukan pemetaan lapangan desa Masaran, d) melakukan analisis ruang yang sesuai dengan kebutuhan, e) membuat gambar pra-desain berupa gambar site-plan, denah dan perspektif, f) dari bahan pra-desain yang telah disusun, dilakukan diskusi dengan semua tim, perangkat desa, tokoh masyarakat dan pengguna untuk mendapatkan masukan dan saran untuk perbaikan pra-desain. g) setelah mendapat persetujuan gambar pradesain maka dibuat perhitungan struktur gambar detailnya untuk gambar pelaksanaan konstruksi, h) penyusunan gambar detail untuk pelaksanaan konstruksi, i) Penyusunan analisa dan Rencana Anggaran Biaya (RAB).

Tahap Akhir dari pendampingan ini adalah meningkatkan peran aktif mitra (perangkat desa dan masyarakat Masaran).Mitra akan menjadi pelaksana dalam revitalisasi lapangan Masaran.

\section{HASIL DAN PEMBAHASAN}

Lokasi lapangan Masaran berada di antara kota Solo dan Sragen. Lapangan Masaran yang terletak di jalur antar provinsi, yaitu jalur Solo-Sragen (Jawa Tengah), Ngawi, Madiun dan Bojonegoro serta kota-kota yang berada di Jawa Timur. Dengan demikian, posisi lapangan ini sangat strategis apabila dikelola dengan baik. Selama ini lapangan Masaran hanya sebagai lapangan untuk sepak bola dan sebagai lokasi upacara pada event-event tertentu. Kondisinya kurang terjaga dengan baik.

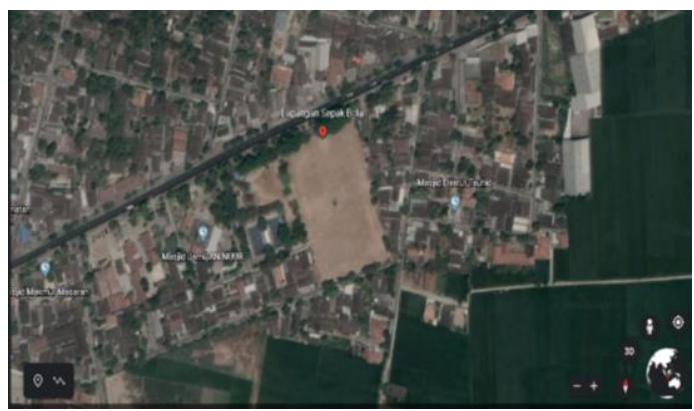

Gambar 1. Lokasi Obyek Pengabdian Lapangan Desa Masaran, Sragen

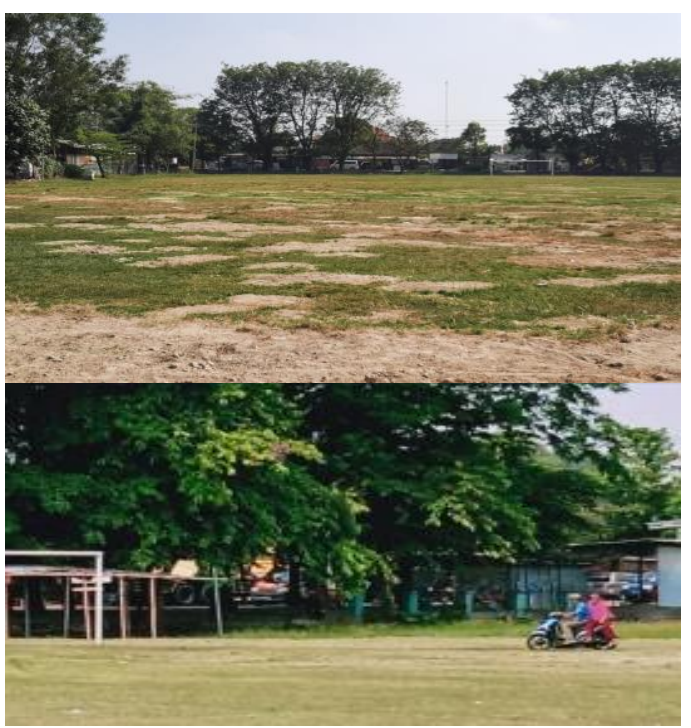

Gambar 2. Kondisi Lapangan

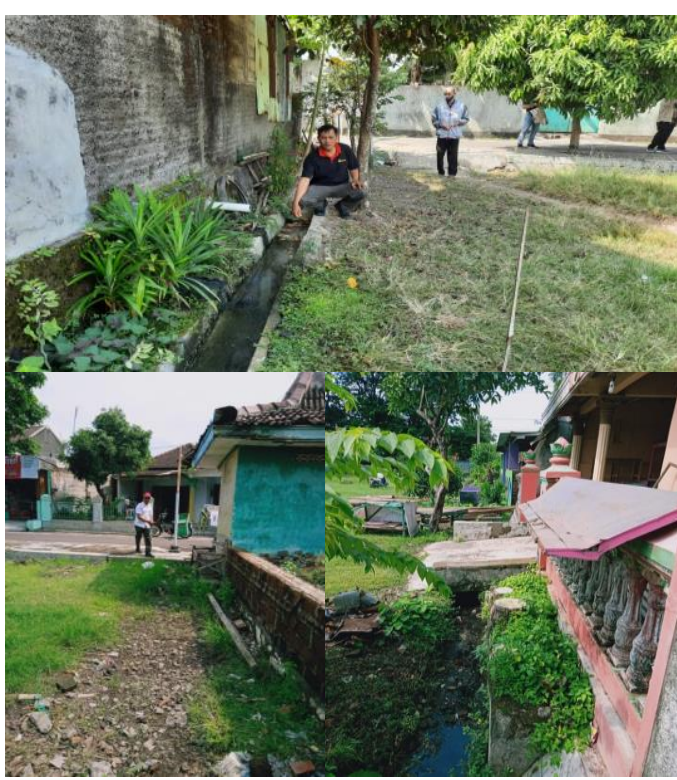

Gambar 3. Kondisi Drainase Pinggir Lapangan Belum Direncanakan

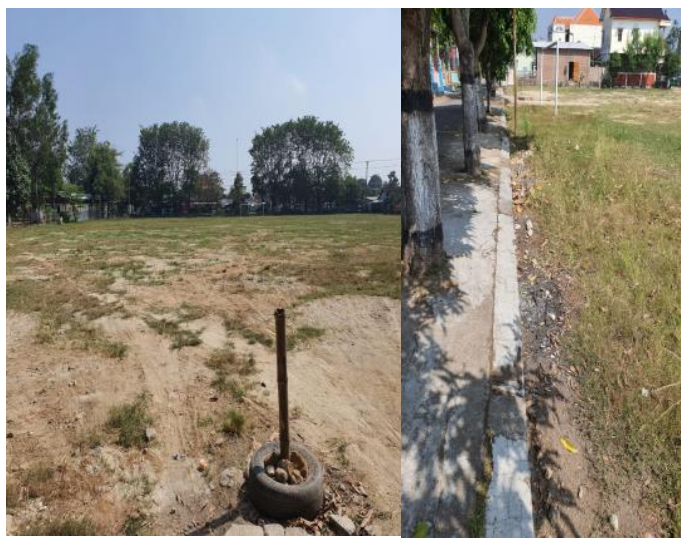


Gambar 4. Kondisi Permukaan dan Bagian Pinggir Lapangan

Berangkat dari kondisi lapangan dan kepentingan-kepentingan warga yang dihimpun dari perangkat Desa dan masyarakat desa Masaran maka tim pengabdian masyarakat Fakultas Teknik Universitas Tunas Pembangunan Surakarta merumuskan konsep revitalisasi fungsi lapangan Masaran. Konsep revitalisasi yang diterapkan adalah tetap mempertahankan 2/3 luas lahan lapangan sebagai lapangan sepak bola (fungsi lama) dan 1/3 luas lahan dari lapangan untuk fungsi-fungsi lain (fungsi baru) yang diharapkan dapat memberikan manfaat bagi masyarakat desa Masaran dan sekitarnya. Adapun konsep penataan ruangnya adalah sebagai berikut: a) 2/3 luas lahan untuk lapangan sepak bola, yang dikelilingi lintasan joging track. Penataan lahan lapangan dilakukan dengan pengurugan dan penanaman rumput yang baik, bisa digunakan bermain sepak bola dengan baik dan dengan sistem drainase yang direncanakan mengelilingi lahan lapangan. Tepi lapangan direncanakan untuk lintasan joging track sehingga bisa dimanfaatkan oleh masyarakat yang memiliki hoby lari/jalan kaki, b). Sistem drainase yang berada di pinggir dan mengelilingi lapangan sepak bola, di bagian atas/penutup saluran ditutup dengan beton, bisa sebagai akses bagi warga yang rumahnya berada di tepi lapangan, c) 1/3 luas lahan dari lapangan, diperuntukkan untuk kegiatan olah raga yang bersifat kekeluargaan, seperti senam, terapi, duduk-duduk santai, terapi dan play ground anak. Di setiap titik direncanakan penanaman pohon yang rindang sehingga menciptakan suasana yang teduh, d) bagian depan dari lahan lapangan ini, direncanakan untuk ruang-ruang publik, tempat berjual beli makanan dan pakaian serta produk-produk lokal dari masyarakat Masaran sehingga produk lokal akan dikenang ke luar daerah. Area parkir yang cukup luas dipersiapkan untuk masyarakat dan orang lain yang sekedar untuk beristirahat, sambil membeli makanan dan pakaian.

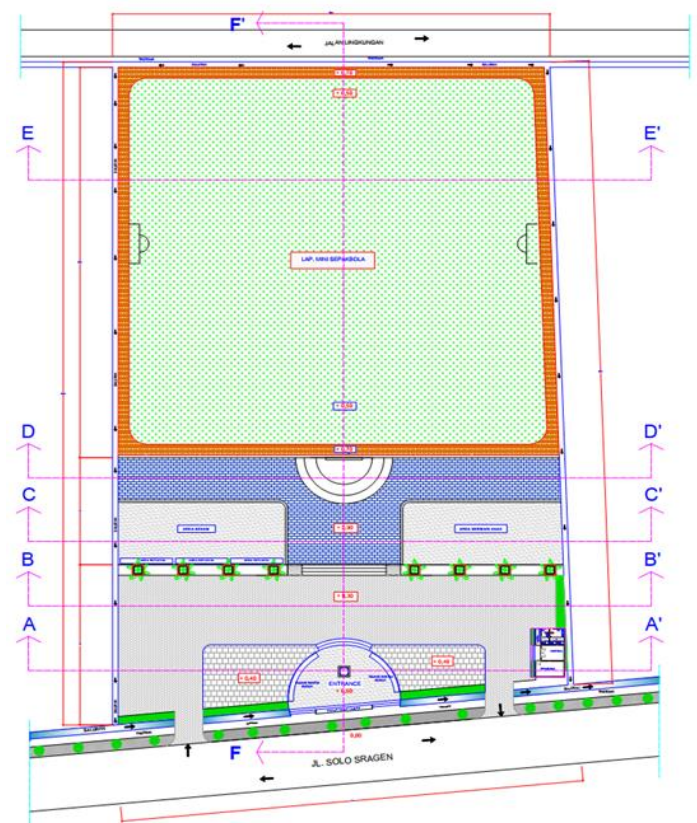

Gambar 5. Revitalisasi Tata Ruang Lapangan Desa Masaran

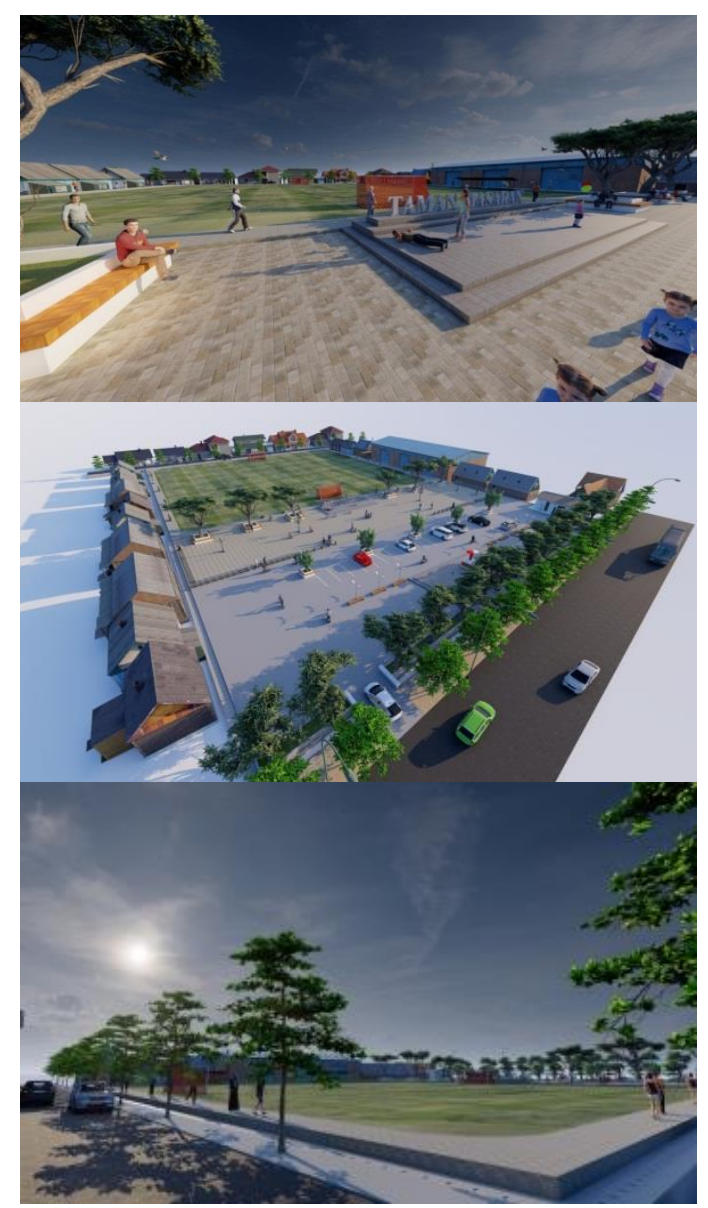


Gambar 6. Suasana Revitalisasi Fungsi Lapangan Desa Masaran

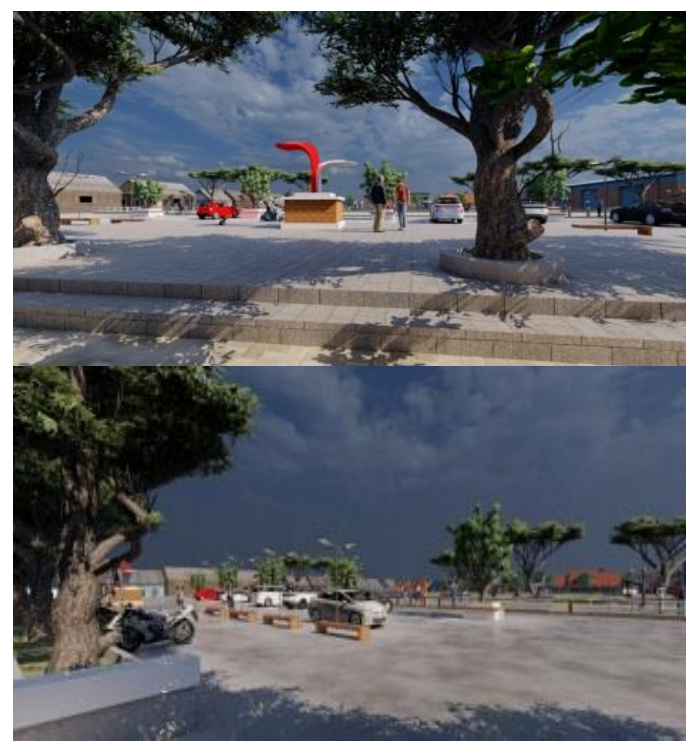

Gambar 7. Suasana Revitalisasi Fungsi Lapangan Desa Masaran

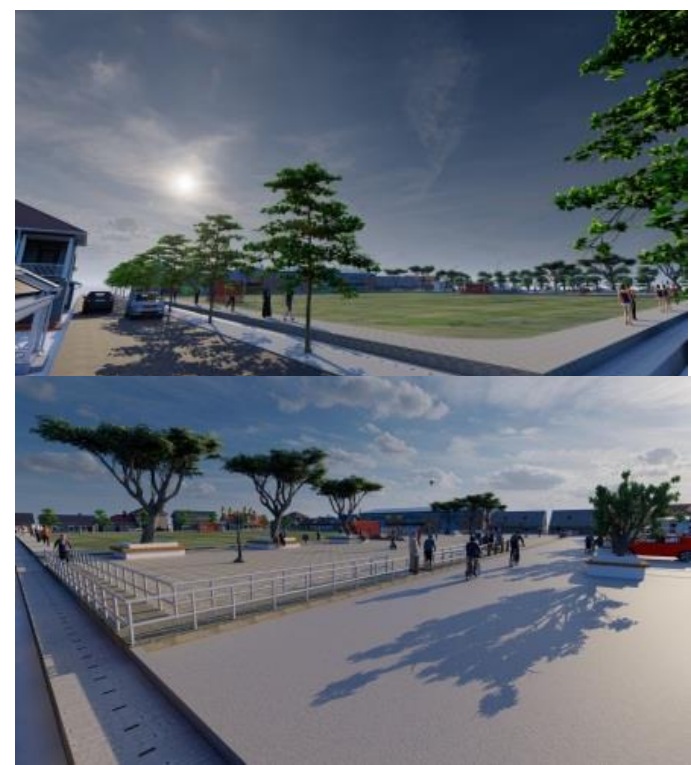

Gambar 8. Suasana Revitalisasi Fungsi Joging dan Terapi

Konsep revitalisasi lapangan desa menekankan pada fungsi lapangan, dimana fungsi lapangan yang dahulu hanya untuk bermain sepak bola, kemudian jarang digunakan. Sekarang, dengan penataan ruang luar mampu menampung beberapa aktifitas. Selain olahraga, aktifitas berkumpul (refreshing), space untuk pedagang keliling dengan sepeda motor diberikan lokasi. Terdapat pula space untuk masyarakat sekitar bisa berdagang, hasil dari produksi sendiri sehingga fungsi ekonomi pun tercapai.

\section{PENUTUP}

Lapangan yang selama ini dirasakan semakin berkurang manfaatnya bagi masyarakat, akan dikembangkan sesuai dengan kebutuhan masyarakat saat ini. Luasan lapangan yang luas, bisa dikelola untuk berbagai kepentingan. Tidak hanya di bidang olahraga, namun juga bidang rekreasi dan ekonomi. Penyediaan wadah untuk berjualan, diharapkan masyarakat bisa menjual produknya dari hasil buatan sendiri.

Revitalisasi lapangan, terkait erat dengan penataan ruang kawasan di lingkup lapangan, meliputi sistem drainase, sistem jalan lingkungan, pengendalian genangan/banjir dan penghijauan. Perencanaan yang direncanakan oleh ahli di bidangnya akan memberikan kemudahan bagi pemerintah desa untuk menyiapkan plan pembangunan lapangan yang berkelanjutan. Berdasarkan hal tersebut maka kolaborasi antara pemerintah desa dan perguruan tinggi ke depannya bisa dijalankan dan ditingkatkan sehingga membawa manfaat bagi masyarakat.

Sasaran desa mitra/desa dampingan untuk pengabdian masyarakat oleh perguruan tinggi semestinya semakin ditingkatkan. Sesuai dengan kebutuhan yang benarbenar dibutuhkan oleh masyarakat. Oleh karena itu tema pendampingan dari perguruan tinggi perlu diprioritaskan untuk proyek-proyek yang bisa bermanfaat bagi masyarakat.

\section{UCAPAN TERIMA KASIH}

Dalam kesempatan ini penulis dan tim pengabdian menyampaikan terimakasih kepada Universitas Tunas Pembangunan (UTP) Surakarta dan 
Bapak Kepala Desa dan Perangkat Desa Masaran, tokoh masyarakat serta semua pihak yang telah membantu pelaksanaan penelitian pengabdian masyarakat Revitalisasi Lapangan Desa Masaran, di Desa Masaran, Kecamatan Masaran, Kabupaten Sragen.

\section{DAFTAR PUSTAKA}

Ellizar, Estika. 2017. Penataan Ruang Luar Pada Lapangan GasibuBandung, Architecture and Environment Journal of Krisnadwipayana, Vol 2, No 1.

Iswanto, Danoe, 2006. "Kajian Ruang Publik Ditinjau Dari Segi proporsi Skala dan Enclosure, Jurnal Ilmiah Perancangan Kota \& Permukiman, 5, No. 2, 74-81

Hartoyo, H. Santoni. 2018. Kriteria Ruang Publik Kalijodo Pendukung Aksesibilitas dan Peningkatan Aktivitas. Jurnal
Teknik Arsitektur ARTEKS, 2, No. 2 ISSN 2541-0598

Setionurjaya, A., Tyas, W.P. 2018. Kajian Persepsi Masyarakat DKI Jakarta Terhadap Kawasan Urban Heritage Bung Karno. Jurnal Pembangunan Wilayah dan Kota, 14, No. 2, 83-93.

Winangsih, Erna. 2010. Estetika Simbolis - Sensori Pada Ruang Publik di Alun-Alun Malang. Local Wisdom Jurnal Ilmiah Online, 2, No.3, 20-28.

Wulandari, Henny. 2014. Eksplorasi Pengalaman Panca Indera Untuk Perancangan Interior. Dimensi Interior, 12, No. 2, 85-90Kim HJ, Hahm TS dan Min DB. 2007. Hydroperoxide as a prooxidant in the oxidative stability of soybean oil. Journal of the American Oil Chemists' Society 84(3):349-355. 